\title{
UTJECAJ TRETMANA SJEMENA NA ZDRAVSTVENO STANJE SJEMENA I POČETNI RAST PAPRIKE
}

\author{
INFLUENCE OF SEED TREATMENT ON THE HEALTH OF SEED \\ AND INITIAL GROWTH OF PEPPERS
}

\author{
Svjetlana Matotan, Z. Matotan, Marina Palfi
}

\section{SAŽETAK}

Istraživanje utjecaja temperature (konstantna $20^{\circ} \mathrm{C}$ i izmjenljiva $20-30^{\circ} \mathrm{C}$ ) $\mathrm{i}$ tretmana sjemena $(\mathrm{NaOCl}, \mathrm{M}$-metalaksil, karboksin+tiram i netretirano sjeme kao kontrola) na energiju klijanja, klijavost i zdravstveno stanje sjemena provedeno je u laboratorijskim uvjetima na sjemenu paprike sorte Slavonka. Rezultati su pokazali statistički značajan učinak temperature, tretmana i njihove interakcije na energiju klijanja sjemena paprike, dok kod klijavosti sjemena tretmani nisu pokazali signifikantne razlike. Najveća energija klijanja bila je u karboksin+tiram tretmanu kod izmjenljive temperature (76\%).

Statistički značajan učinak temperature, tretmana i njihove interakcije utvrđen je za razvoj fitopatogenih gljiva Alternaria spp, Cladosporium sp. i Penicillium sp. Za razvoj Fusarium spp. temperature nisu pokazale statistički značajnu razliku, kao niti interakcija temperature i tretmana za razvoj Aspergillus spp.

Na temelju naših rezultata možemo zaključiti da se učinkovitim tretmanima može poboljšati kvaliteta sjemena i smanjiti količina fungicida potrebnih za suzbijanje bolesti sjemena.

Ključne riječi: paprika, tretmani, energija klijanja, klijavost, zdravstveno stanje sjemena

\section{ABSTRACT}

A study of the influence of temperature (constant $20^{\circ} \mathrm{C}$ and changeable $\left.20-30^{\circ} \mathrm{C}\right)$ and seed treatment $(\mathrm{NaOCl}, \mathrm{M}$-metalaxyl, carboxine + thiram and untreated seed as control) on germination energy, germination and health status of seeds was carried out in laboratory conditions on seed pepper variety Slavonka. The results showed a statistically significant effect of temperature, 
Svjetlana Matotan i sur.: Utjecaj tretmana sjemena na zdravstveno stanje sjemena i početni rast paprike

treatment and their interaction on the germination energy of pepper seeds, while seed germination treatments did not show significant differences at all. The highest germination energy was in the carboxine + thiram treatment at changeable temperature $(76 \%)$.

A statistically significant effect of temperature, treatment and interaction was determined on the development of phytopathogenic fungi Alternaria spp, Cladosporium sp. and Penicillium sp. Temperatures did not show any statistically significant difference in the development of Fusarium spp., nor the interaction of temperature and treatment in the development of Aspergillus spp.

Based on our results we can conclude that effective treatments can improve seed quality and reduce the amount of pesticides needed to control the disease.

Key words: pepper, treatments, germination energy, germination, health status of the seeds

\section{UVOD}

Paprika (Capsicum annuum L.) je povrće koje se koristi u prehrani ljudi širom svijeta. Odličan je izvor škroba, dijetalnih vlakana, proteina, lipida, minerala i drugih hranjivih tvari. Osim toga sadrži fitokemikalije $s$ antioksidativnim svojstvima koje pozitivno utječu na ljudsko zdravlje (Sun i sur., 2007.; O'Sullivan i sur., 2010.). Osobito je značajan izvor vitamina C, $\beta$-karotena i kalcija te su njezini plodovi drugi u svijetu u potrošnji povrća (Mateos i sur., 2009.). Osim plodova i sjemenke paprike su potencijalni izvor bioaktivnih spojeva koji se mogu koristiti u prehrambenoj industriji (Silva i sur., 2013.). Paprika je povrtna kultura izuzetno visokih zahtjeva za toplinom u početnim fazama razvoja. Najbrže klijanje i nicanje je pri temperaturama $25-30^{\circ} \mathrm{C}$ (Matotan, 2004.). Sjetva pri nižim temperaturama često ima za posljedicu neujednačeno klijanje i nicanje, naročito pri izravnoj sjetvi (O'Sullivan i Bouw, 1984.). Osim toga, mlade su biljčice paprike u početnoj fazi razvoja naročito osjetljive na infekciju patogenim mikroorganizmima koji se nalaze na sjemenu ili u tlu. Sjemenom se prenose biljni patogeni koji u početnim fazama rasta i razvoja, ali i kasnije u vegetaciji mogu uzrokovati propadanje usjeva i smanjenje uroda. Bolesti koje se prenose sjemenom mogu ozbiljno utjecati na prinos i kvalitetu plodova. Neki patogeni poput Colletotrichum capsici mogu prouzročiti gubitak u polju i do 100\% (Liestiani i Fikri, 2012.). Fitopatogene gljive Alternaria alternata, Aspergillus niger, 
Svjetlana Matotan i sur.: Utjecaj tretmana sjemena na zdravstveno stanje sjemena i početni rast paprike

A. versicolor, Fusarium oxysporum, Penicillium digitatum, Phytopthora sp., Rhizoctonia sp., Rhizopus arrhizus i Rh. stolonifer, česti patogeni na sjemenu rajčice, paprike i patlidžana (Ismael, 2010.), mogu smanjiti kvalitetu sjemena. Neki biljni patogeni poput vrsta Alternaria teško se suzbijaju fungicidima. Tretiranje fugicidima može smanjiti, ali ne i potpuno eliminirati zarazu (Coles i Wicks, 2003.) stoga je važno proizvesti zdrav rasad te posredno smanjiti zarazu sjemena tim patogenima. Naročito je teško stanje $u$ ekološkoj, ali i konvencionalnoj poljoprivredi jer nema dovoljno registriranih fungicida za suzbijanje biljnih bolesti u usjevu i na sjemenu. Iako se razvoj biljnih bolesti smanjio upotrebom sintetskih fungicida zbog njihovog štetnog utjecaja na ljude i okoliš, alternativne metode zaštite poljoprivrednih kultura imaju sve veću važnost. Stoga je sjetva kvalitetnog i zdravstveno ispravnog sjemena najvažnija preventivna mjera u suzbijanju patogena sjemena. Različiti tretmani mogu smanjiti inokulum sjemena, ali često nisu u mogućnosti u potpunosti eliminirati bolesti koje se prenose sjemenom bez utjecaja na vitalnost sjemena (Forsberg i sur., 2002.). Provode se mnoga istraživanja u cilju pronalaska načina kako pomoći sjemenu poljoprivrednih kultura da što prije proklije i omogućiti mladim biljčicama uvjete brzog rasta i razvoja (Yildirim i sur., 2000.; Palfi, 2007.; Sutariati, 2014.; Nei i sur., 2015.; Lisjak i sur., 2015.; Sadeghi i sur., 2016.).

Cilj ovog istraživanja bio je ispitati utjecaj različitih kemijskih pripravka na energiju klijanja, klijavost sjemena te zarazu sjemena paprike (C. annuum L.) fitopatogenim gljivama.

\section{MATERIJAL I METODE}

Ispitivanja su provedena u laboratoriju za ispitivanje sjemena Podravka d.d. Koprivnica na sjemenu paprike sorte Slavonka. Sjeme paprike tretirano je $\mathrm{NaOCl}-\mathrm{om}$ potapanjem u otopinu 1:5 $(10 \mathrm{ml} \mathrm{NaOCl}-\mathrm{a}+50 \mathrm{ml}$ destilirane vode $)$ u trajanju od 10 minuta, M-metalaksil-om raspršivanjem $0,01 \mathrm{ml}$ sredstva / $10 \mathrm{~g}$ sjemena i karboksin + tiram-om raspršivanjem $0,01 \mathrm{ml}$ sredstva / $10 \mathrm{~g}$ sjemena. Kao kontrola uzeto je netretirano sjeme.

Energija klijanja i klijavost sjemena

Sjeme je stavljeno u Petrijeve zdjelice na dvoslojni filter papir koji je prethodno navlažen destiliranom vodom. Naklijavanje sjemena paprike provedeno je u klima komori Binder KBW 100, pri svjetlosnom režimu $8 \mathrm{~h}$ 
Svjetlana Matotan i sur.: Utjecaj tretmana sjemena na zdravstveno stanje sjemena i početni rast paprike

dan/16 h noć na dva temperaturna režima (konstantna temperatura od $20^{\circ} \mathrm{C} \mathrm{i}$ izmjenljiva temperatura $20-30^{\circ} \mathrm{C}$, pri čemu je niža temperatura trajala $16 \mathrm{~h}$, a viša $8 \mathrm{~h}$ ). Svaka varijanta je postavljena u 4 ponavljanja po 100 sjemenki. Prema Pravilniku o metodama uzorkovanja i ispitivanja kvalitete sjemena (NN 99/08) sedmi dan nakon početka naklijavanja očitavala se energija klijanja, a nakon 14 dana klijavost sjemena.

Zdravstveno stanje sjemena

Netretirano sjeme (kontrola) i sjeme tretirano tretmanima $(\mathrm{NaOCl}, \mathrm{M}$ metalaksil i karboksin+tiram) stavljeno je u Petrijeve zdjelice na dvoslojni filter papir koji je prethodno navlažen s $10 \mathrm{ml}$ sterilne vode / Petrijevoj zdjelici. Inkubacija sjemena paprike provedena je u klima komori Binder KBW 400 (2007.) na dva temperaturna režima (konstantna temperatura od $20^{\circ} \mathrm{C}$ i izmjenljiva temperatura $20-30^{\circ} \mathrm{C}$, pri čemu je niža temperatura trajala $16 \mathrm{~h}$, a viša 8 h). Sjeme je inkubirano u uvjetima izmjene svjetla i tame (12 sati svjetla i 12 sati tame). Svaka varijanta je postavljena u 4 ponavljanja po 100 sjemenki.

Deseti dan nakon početka inkubacije izvršena je determinacija patogena sjemena paprike prema međunarodnim ISTA pravilima determinacije (Mathur i Kongsdal, 2003).

Statististička analiza podataka

Statistička obrada eksperimentalnih podataka provedena je nakon prethodne transformacije postotka, ovisno o ispitivanim parametrima pomoću sljedeće formule: $Y=\arcsin \sqrt{(\mathrm{x} \% / 100)}$ (Hinkelmann i Kempthorne, 1994). Dobivene vrijednosti statistički su obrađene dvosmjernom analizom varijance (ANOVA) pomoću statističkog programa GraphPad. Razlike su procijenjene pomoću Tukey testa višestruke usporedbe. Rezultati su smatrani statistički značajnima ako je $\mathrm{p}<0,05$. Rezultati su prikazani u realnoj vrijednosti.

\section{REZULTATI I DISKUSIJA}

Energija klijanja i klijavost sjemena

Analizom varijance utvrđen je statistički značajan učinak $(p<0,01)$ temperature (F-test 281,7), $(\mathrm{p}<0,01)$ tretmana (F-test 9,65) i njihove interakcije $(p<0,05)(F-t e s t 3,20)$ na energiju klijanja sjemena paprike, dok kod klijavosti 
Svjetlana Matotan i sur.: Utjecaj tretmana sjemena na zdravstveno stanje sjemena i početni rast paprike

sjemena tretmani uopće nisu pokazali signifikantne razlike (Tablica 1). Statistički značajan učinak temperature, tretmana i njihove interakcije $(\mathrm{p}<0,01)$ utvrđen je za razvoj fitopatogenih gljiva Alternaria spp, Cladosporium sp. i Penicillium sp. Za razvoj gljive Fusarium spp. temperature nisu pokazale statistički značajnu razliku $(\mathrm{p}>0,05) \quad($ F-test 1,59$)$, kao niti interakcija temperature i tretmana (F-test 1,98) na razvoj Aspergillus spp.

Tablica 1. Dvofaktorijalna ANOVA za promatrane parametre pod utjecajem temperature, tretmana $\mathrm{i}$ interakcija temperatura $\mathrm{x}$ tretman

Table 1 Two-way ANOVA for observed parameters under the influence temperature, treatments and and interaction temperature $x$ treatments

\begin{tabular}{|l|c|c|c|}
\hline $\begin{array}{c}\text { Promatrani parametri } \\
\text { Observations parameters }\end{array}$ & $\begin{array}{c}\text { Temperatura } \\
\text { Temperature }\end{array}$ & $\begin{array}{c}\text { Tretman } \\
\text { Treatment }\end{array}$ & $\begin{array}{c}\text { Temperatura } \mathrm{x} \text { Tretman } \\
\text { Temperature } \text { Treatment }\end{array}$ \\
\hline $\begin{array}{l}\text { Energija klijanja } \\
\text { (Germination energy) }\end{array}$ & $* *$ & $* *$ & $*$ \\
\hline Klijavost (Germination) & $* *$ & $\mathrm{~ns}$ & $*$ \\
\hline Alternaria $\mathrm{spp}$ & $* *$ & $* *$ & $\mathrm{~ns}$ \\
\hline Aspergillus spp. & $*$ & $* *$ & $* *$ \\
\hline Cladosporium sp. & $* *$ & $* *$ & $* *$ \\
\hline Fusarium $\mathrm{spp}$. & $\mathrm{ns}$ & $* *$ & $* *$ \\
\hline Penicillium $\mathrm{sp}$. & $* *$ & $* *$ & $* *$ \\
\hline
\end{tabular}

$* p<0.05 ; * * p<0.01 ; n s-$ nije statistički značajno (non significant)

Tukey testom višestruke usporedbe analizirani su tretmani za svaki temperaturni režim posebno. Energija klijanja je kod konstantne temperature $\left(20^{\circ} \mathrm{C}\right)$ bila najveća u tretmanu sjemena M-metalaksil-om $(39,8 \pm 8,06)$ i značajno se razlikovala u odnosu na kontrolu $(22,5 \pm 7,51)$, ali ne i u odnosu na ostale tretmane (Slika 1). Najveća energija klijanja kod izmjenljive temperature $(75,5 \pm 7,77)$ bila je u tretmanu sjemena karbiksim+tiram-om, a najmanja u tretmanu s NaOCl-om $(58,8 \pm 2,87)$ iako se nije značajnije razlikovala od kontrole $(62,0 \pm 6,48)$. Kod klijavosti sjemena nisu utvrđene statistički značajne razlike među tretmanima niti u jednom temperaturnom režimu (Slika 2). Naši rezultati su u skladu s rezultatima Parađiković i sur. (2008.) koji su utvrdili da je tretman sjemena cvjetnih vrsta biostimulatorima dao pozitivan učinak na energiju klijanja, ali se kod klijavosti taj pozitivan učinak gubi. Bukvić i sur. (2010.) su za ispitivane kultivare crvene djeteline također utvrdili veću klijavost sjemena na višoj temperaturi. Međutim, Palfi i sur. (2017a.) nisu u svojim ispitivanjima utvrdili statistički značajnu razliku u energiji klijanja između sjemena tretiranog stimulatorom klijanja i netretiranog sjemena niti na jednoj temperaturi, ali je zato klijavost povećana kod sjemena tretiranog stimulatorom 
Svjetlana Matotan i sur.: Utjecaj tretmana sjemena na zdravstveno stanje sjemena i početni rast paprike

klijanja na nižoj i višoj temperaturi. Bolju klijavost sjemena i brži razvoj mladih biljčica na nižim temperaturama nakon različitih tretmana sjemena utvrdili su mnogi autori (Korkmaz i Korkmaz, 2009; Ozbay i Susluoglu, 2016.; Samarah i sur., 2016.). Khah i sur. (1992.) navode da učinci NaOCl-a na klijanje sjemena paprike ovise o koncentraciji $\mathrm{NaOCl}-\mathrm{a}$, trajanju tretmana, temperaturi otopine tijekom tretmana, temperaturi inkubacije tijekom ispitivanja klijavosti te starosti sjemena. Jones i Sanders (1987.) su sjemenke paprike natapali vodom, otopinom $\mathrm{KNO}_{3}+12 \mathrm{~K}_{2} \mathrm{HPO}_{4}$ ili otopinom $1,52 \mathrm{KNO}_{3}+1,52 \mathrm{~K}_{2} \mathrm{HP}_{4}$ na $21^{\circ} \mathrm{C}$ kroz 72 odnosno 96 sati. Sjemenke su sušene na zraku i naklijavane na $15^{\circ} \mathrm{C}$, $20^{\circ} \mathrm{C}$ ili $25^{\circ} \mathrm{C}$. Svi tretmani namakanja povećali su i ujednačili klijavost sjemena. Zaključili su da broj dana potrebnih za klijanje sjemena paprike na niskim temperaturama može biti smanjen, a postotak klijanja povećan kod natapanja sjemena u vodi ili otopini $\mathrm{KNO}_{3}+\mathrm{K}_{2} \mathrm{HPO}_{4}$. O'Sullivan i Bouw (1984.) su utvrdili poticajni učinak solnih otopina $\left(\mathrm{KNO}_{3}+\mathrm{K}_{3} \mathrm{PO}_{4} \mathrm{H}_{2} \mathrm{O}\right)$ na klijavost koji je bio najznačajniji kod $12,5^{\circ} \mathrm{C}$. Na toj je temperaturi vrijeme do $50 \%$ klijavosti bilo do 14 dana kraće za tretirano sjeme nego za netretirano sjeme. Autori navode da tretmani sjemena paprike u solnim otopinama nude mogućnost bržeg klijanja i razvoja sadnica na niskim temperaturama.

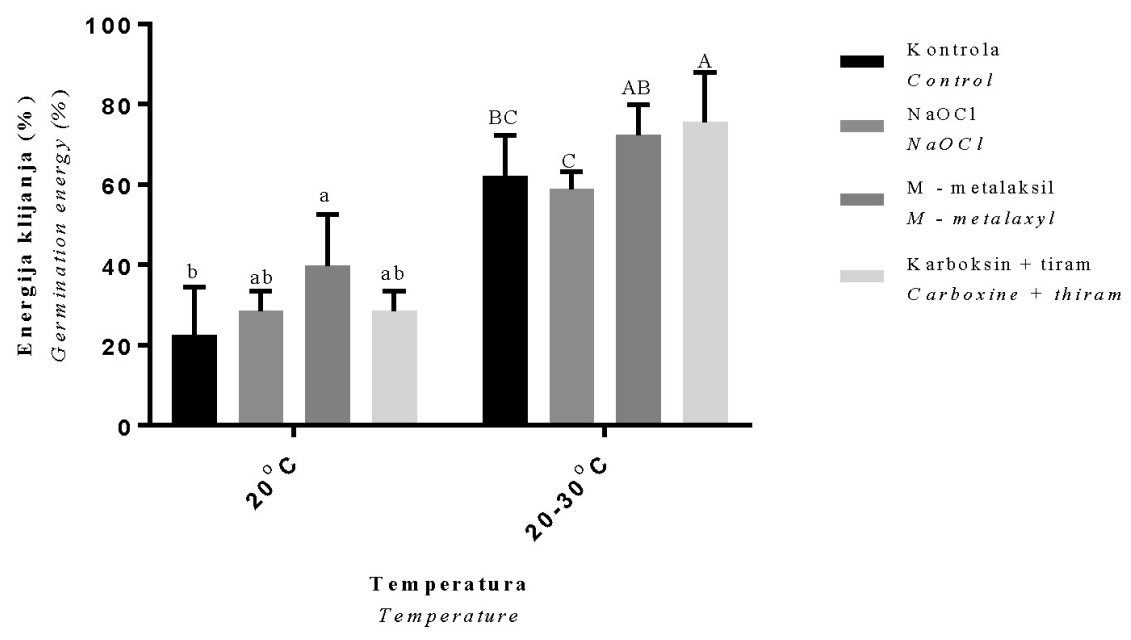

Slika 1. Utjecaj tretmana sjemena na energiju klijanja

Figure 1 Effect of seed treatment on germination energy 
Svjetlana Matotan i sur.: Utjecaj tretmana sjemena na zdravstveno stanje sjemena i početni rast paprike

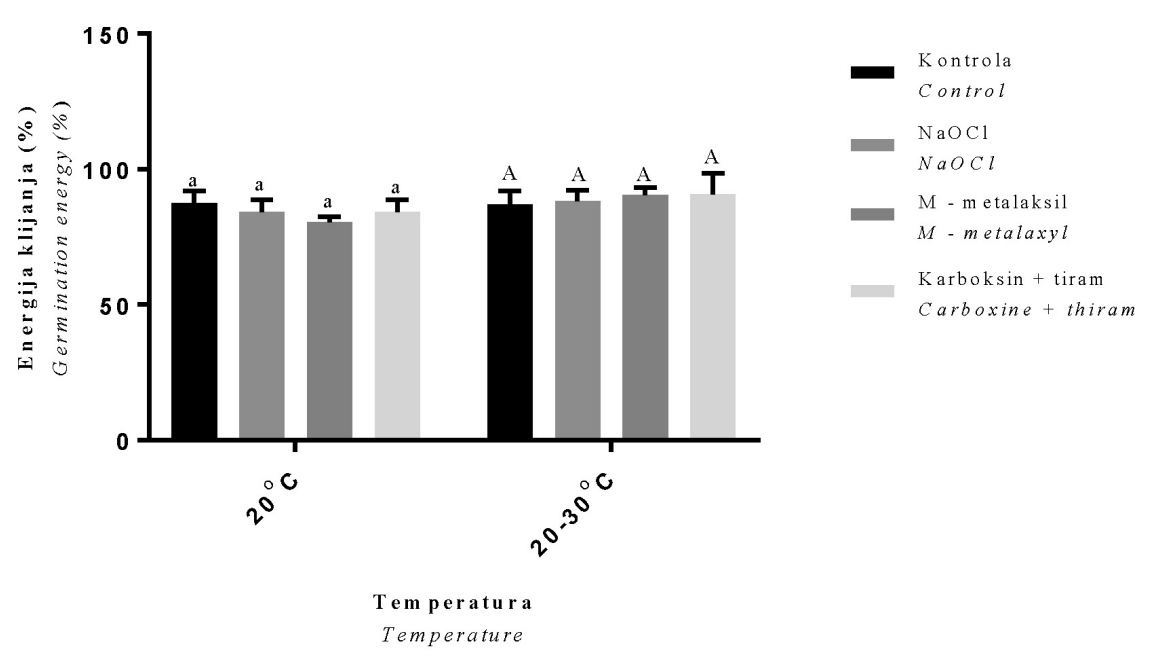

Slika 2. Utjecaj tretmana sjemena na klijavost sjemena

Figure 2 Effect of seed treatment on seed germination

\section{Zdravstveno stanje sjemena}

Nakon isteka vremena inkubacije izvršena je determinacija patogena koji su se razvili na sjemenu i utvrđena je prisutnost fitopatogenih gljiva iz sljedećih rodova: Aletrnaria, Aspergullus, Cladosporium, Fusarium i Penicillium.

Najveći postotak sjemena zaraženog gljivama iz roda Aletrnaria zabilježen je u kontrolnoj varijanti pokusa na konstantnoj temperaturi $\left(20^{\circ} \mathrm{C}\right)(50,5 \pm 8,27)$. Tretmani sjemena imali su manji postotak zaraženosti sjemena ovom gljivom i statistički su se značajno razlikovali od kontrole (Slika 3). Kontrolna varijanta je i kod izmjenljive temperature $\left(20-30^{\circ} \mathrm{C}\right)$ imala najveći postotak zaraženosti gljivama iz roda Alternaria $(16,8 \pm 2,22)$, iako je u odnosu na konstantnu temperaturu broj zaraženih sjemenki bio manji za 34\%. U ovom je temperaturnom režimu $\mathrm{NaOCl}$ najbolje suzbio ovu gljivu $(0,8 \pm 0,50)$, ali se nije statistički značajno razlikovao od tretmana karboksin + tiram.

Zaraženost sjemena gljivama iz roda Aspergullus bila je najmanja u tretmanu s M-metalaksiol-om i pri izmjenljivoj $(3,5 \pm 1,73)$ i konstantnoj $(3,0 \pm 0,82)$ temperaturi (Slika 4). Sjeme tretirano NaOCl-om i karboksin + tiram-om nije se statistički razlikovalo od kontrolnih varijanti u oba temperaturna režima. 
Svjetlana Matotan i sur.: Utjecaj tretmana sjemena na zdravstveno stanje sjemena i početni rast paprike

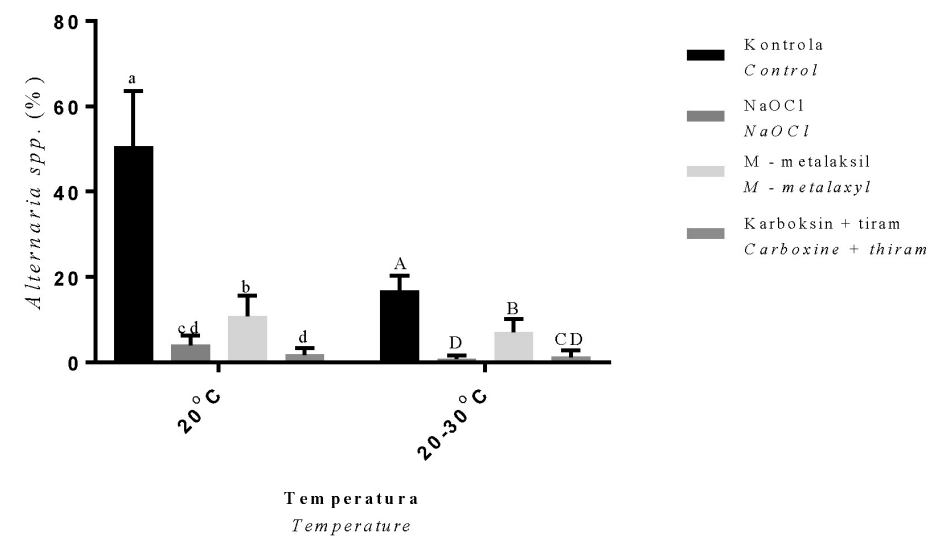

Slika 3. Utjecaj tretmana sjemena na rast gljivice Alternaria spp.

Figure 3 Effect of seed treatment on growth of fungi Alternaria spp.

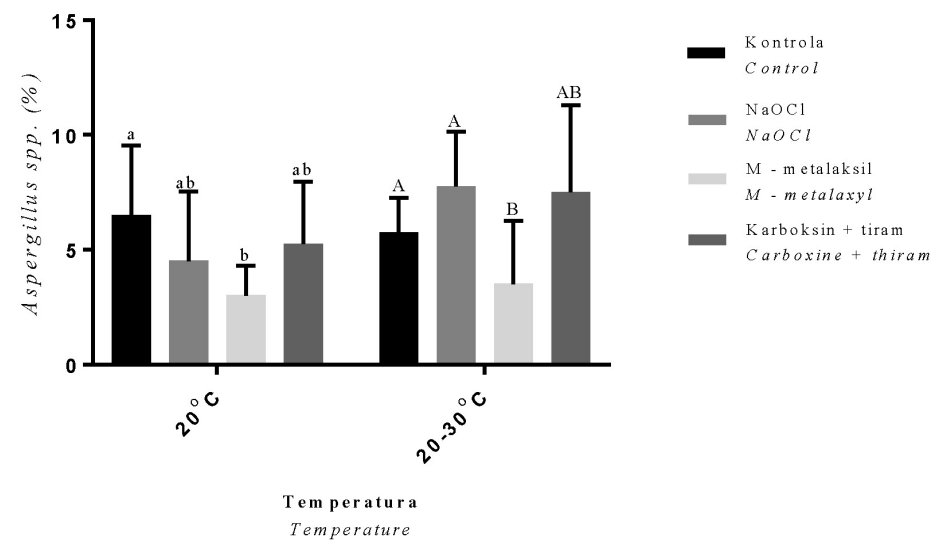

Slika 4. Utjecaj tretmana sjemena na rast gljivice Aspergillus spp.

Figure 4 Effect of seed treatment on growth of fungi Aspergillus spp.

Tretman sjemena NaOCl-om najbolje je suzbio gljive iz roda Cladosporium pri višoj $(0,8 \pm 0,50)$ i nižoj $(2,0 \pm 0,82)$ temperaturi (Slika 5$)$. Pri temperaturi od $20^{\circ} \mathrm{C}$ najveći postotak zaraženih sjemena Cladosporium vrstama bio je kod kontrole $(31,3 \pm 7,50)$, zatim slijedi M-metalaksil $(10,0 \pm 3,65)$ i karboksin+tiram $(3,5 \pm 1,29)$. Kod izmjenljive temperature najveći postotak zareženih sjemenki ovom gljivom imali su kontrola $(5,0 \pm 1,41)$ i M-metalaksil $(3,8 \pm 0,96)$ čije se djelovanje nije statistički značajno razlikovalo. 
Svjetlana Matotan i sur.: Utjecaj tretmana sjemena na zdravstveno stanje sjemena i početni rast paprike

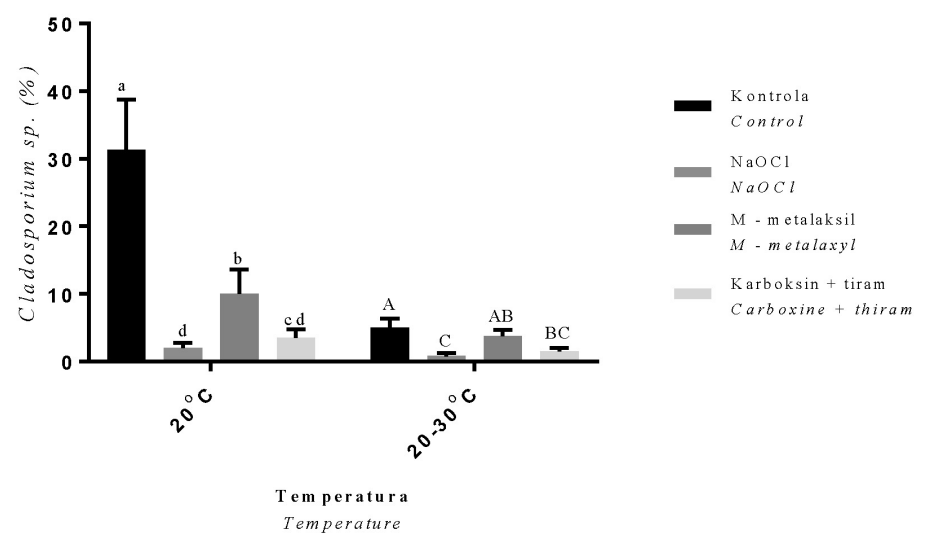

Slika 5. Utjecaj tretmana sjemena na rast gljivice Cladosporium sp.

Figure 5 Effect of seed treatment on growth of fungi Cladosporium sp.

Najveći postotak zaraženih sjemenki Fusarium vrstama imale su kontrole u oba temperaturna režima (Slika 6). Svi tretmani sjemena kod konstantne temperature $\left(20^{\circ} \mathrm{C}\right)$ statistički su se značajno razlikovali od kontrole, a M-metalaksil je potpuno suzbio rast ove gljive. Pri izmjenljivoj temperaturi $\left(20-30^{\circ} \mathrm{C}\right)$ tretman $\mathrm{s}$ karboksin+tiram-om potpuno je suzbio razvoj Fusarium vrsta, dok se tretman s M-metalaksil-om nije statistički značajno razlikovao od kontrole.

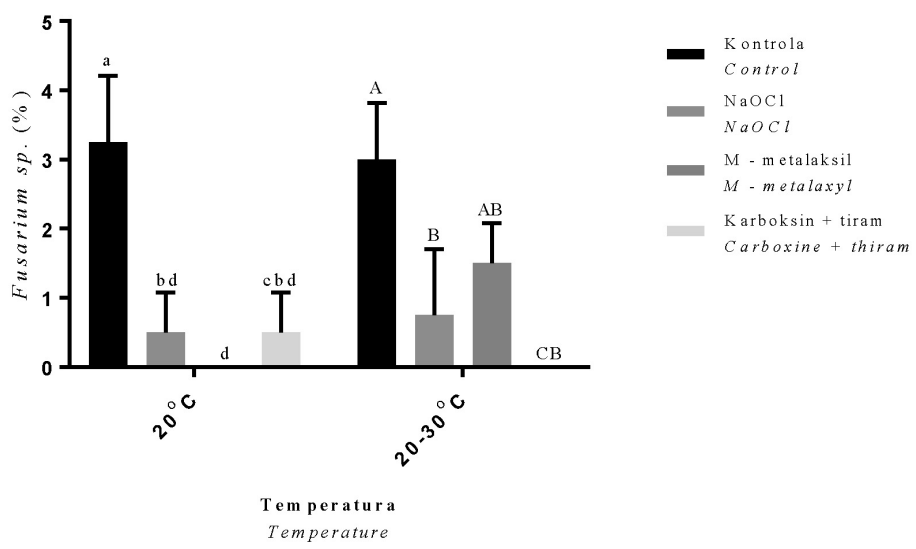

Slika 6. Utjecaj tretmana sjemena na rast gljivice Fusarium spp.

Figure 6 Effect of seed treatment on growth of fungi Fusarium spp. 
Svjetlana Matotan i sur.: Utjecaj tretmana sjemena na zdravstveno stanje sjemena i početni rast paprike

Najslabije djelovanje na Penicillium vrste imao je tretman NaOCl-om na konstantnoj temperaturi $\left(20^{\circ} \mathrm{C}\right)$ (Slika 7$)$. Kontrolna varijanta i tretman $\mathrm{s}$ M-metalaksiol-om nije se statistički značajno razlikovao. Najbolje djelovanje imao je tretman karboksin+tiram kod kojeg je zabilježen najmanji postotak sjemenki zaraženih ovom gljivom $(8,0 \pm 1,83)$. Kod izmjenljive temperature $\left(20-30^{\circ} \mathrm{C}\right)$ nije bilo statistički značajnih razlika između tretmana u zaraženosti sjemena ovim patogenom.

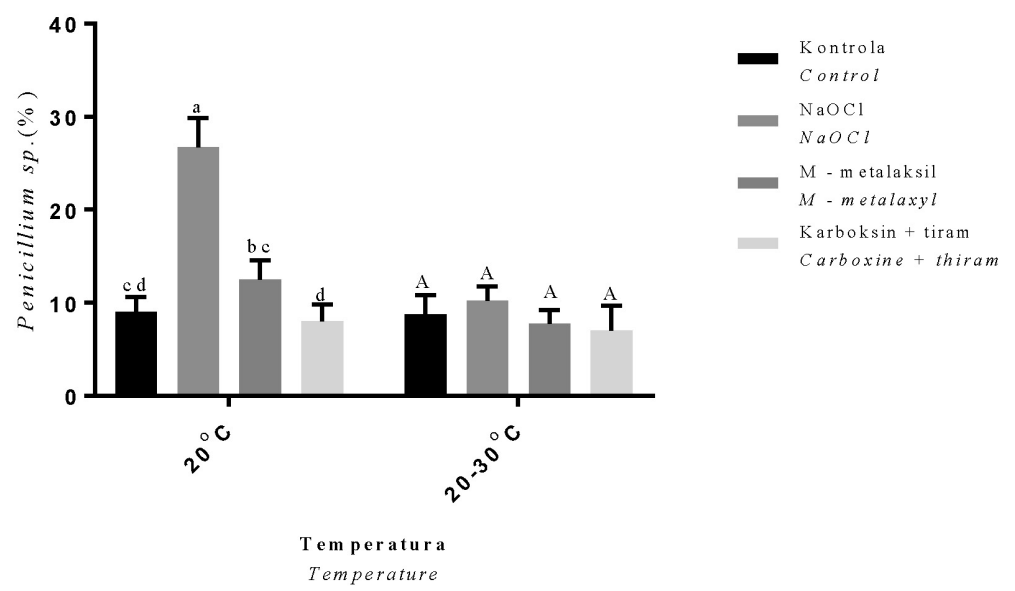

Slika 7. Utjecaj tretmana sjemena na rast gljivice Penicillium sp.

Figure 7 Effect of seed treatment on growth of fungi Penicillium sp.

Zarazu sjemena gljivama iz rodova Aletrnaria i Aspergillus navodi i Ismael (2010.). Gljive koje su izolirane iz rajčice, sjemenki paprike i patlidžana u regiji Germian / Iran su: Alternaria alternata, Aspergillus niger, A.versicolor, Fusarium oxysporum, Penicillium digitatum, Phytopthora sp., Rhizoctonia sp., Rhizopus arrhizus i Rh.stolonifer. Najveći postotak ponavljanja bio je 0,77 za $A$. niger, a najniži 0,05 za $F$. oxysporum. U ispitivanjima sjemena čili paprike najzastupljenije gljive bile su Colletothrichum capsici, Aspergillus niger i A. flavus $(54,75 \%, 44,00 \%$ i 29,75\%) (Chigoziri i Ekefan, 2013.). Balogun i sur. (2005.) su iz plodova i sjemena paprike izolirali Penicillium digitatum, Aspergillus flavus i Aspergillus niger. Nega i sur. (2003.) su ispitivali pet kultiviranih biljnih vrsta (mrkva, kupus, celer, peršin, matovilac) i njihove najznačajnije uzročnike bolesti sjemena (Alternaria spp., Phoma spp., Septoria spp., Peronospora valerianellae, Xanthomonas spp.). Utvrdili su da se patogeni sjemena mogu smanjiti bez značajnijih gubitaka klijanja vrućim 
Svjetlana Matotan i sur.: Utjecaj tretmana sjemena na zdravstveno stanje sjemena i početni rast paprike

vodenim tretmanima na $50^{\circ} \mathrm{C}$ tijekom 20 do 30 minuta odnosno $53^{\circ} \mathrm{C}$ tijekom 10 do 30 minuta. Na višoj temperaturi, međutim, vrijeme tretmana mora biti smanjeno kako bi se izbjegla smanjena klijavost osjetljivih usjeva. Worrall i sur. (2013.) navode da su biljke uzgojene iz sjemena tretiranog jasmonskom kiselinom pokazale povećanu otpornost na zarazu fitopatogenom gljivom Botrytis cinerea, dok je tretman sjemena $\beta$ - aminobutiričnom kiselinom omogućio zaštitu od Oidium neolycopersici. Daniel i sur. (2014.) navode da su biološki tretmani ekstraktima Trichoderma asperellum inhibirali rast Fusariuma oxysporuma. U ispitivanju Samarah i sur. (2016.) fungicid kaptan nije poboljšao klijavost na hladnim tlima te autori sugeriraju da se poboljšanje može postići hidroprimiranjem, nanohitinom ili kitozanom i time omogućiti da se izbjegnu bolesti sjemena i klijanaca na tim tlima. Mao i sur. (1997.) u istraživanjima nekih patogena na sjemenu kukuruza ukazuju na to da neki gljivični ili bakterijski antagonisti imaju potencijal kontrole bolesti koji se može usporediti ili biti čak superiorniji od fungicida kaptana. Fizički tretmani i tretmani biopesticidima, kao što su prirodni spojevi, eterična ulja i biokontrolni agensi pokazali su se također učinkovitima i mogu biti odlična alternativa kemijskoj zaštiti od patogena sjemena (Mancini i Romanazzi, 2013.; Palfi i sur., 2017b.).

\section{ZAKLJUČAK}

Tretmani sjemena mogu pomoći mladim biljkama paprike u bržem rastu i razvoju, naročito $\mathrm{u}$ nepovoljnim uvjetima uzgoja. Neophodna je kontrola zdravstvenog stanja sjemena jer različiti tretmani sjemena djeluju različito na pojedinu vrstu fitopatogenih gljiva. Učinkovitim tretmanima može se poboljšati kvaliteta sjemena i smanjiti količina fungicida potrebna za suzbijanje bolesti.

\section{LITERATURA}

1. Balogun, O.S., Odeyemi, G.A., Fawole, O.B. (2005.): Evaluation of the pathogenic effect of some fungal isolates on fruits and seedlings of pepper (Capsicum spp). Journal of Agricultural Research and Development, 4(2): 159-169.

2. Bukvić, G., Grljušić, S., Stanisavljević, A., Varga, I., Mrkulj, A., Jozić, A. (2010.): Utjecaj temperature i $\mathrm{pH}$ vrijednosti na klijavost sjemena i svojstva klijanaca kultivara crvene djeteline. Sjemenarstvo, 27(1-2): 43-55.

3. Chigoziri, E., Ekefan , E. J. (2013.): Seed-borne fungi of Chilli pepper (Capsicum frutescens) from pepper producing areas of Benue state, Nigeria. Agriculture and Biology Journal of America (ABJNA), 4: 370-374. 
Svjetlana Matotan i sur.: Utjecaj tretmana sjemena na zdravstveno stanje sjemena i početni rast paprike

4. Coles, R.B., Wicks, T.J., (2003.): The incidence of Alternaria radicina on carrot seeds, seedlings and roots in South Australia. Australasian Plant Pathology, 32(1): 99-104.

5. Daniel, H.C.F., Wilfredo, F.F., Francisco, C.R., Gabriel, G.M., Epifanio, C.D.Á. (2014.): Antibiosis In vitro of Trichoderma Strains Metabolic Extract on Mycelial Growth and Reproductive Capacity of Fusarium oxysporum Isolated from Pepper Plants (Capsicum annuum L.). British Biotechnology Journal, 4(4): 387.

6. Forsberg, G., Andersson, S., Johnsson, L. (2002.): Evaluation of hot, humid air seed treatment inthinlayers and fluidizedbeds for seed pathogen sanitation. Journal of Plant Diseases and Protection, 109: 357-370.

7. GraphPad Software Prism 5, San Diego, CA, USA. Dostupno: http://www.graphpad.com/ (pristupljeno 24. svibnja 2017).

8. Hinkelmann, K., Kempthorne, O. (1994.): Design and Analysis of Experiments. Vol. 1, Wiley and Sons, New York.

9. Ismael, J.H. (2010.): Isolation and identification of some fungi from certain solanaceous seeds in Sulaimania and Germian regions and thei rexudate effects on germination rate. Agriculture and Biology Journal of North America, 1(4): 615-619.

10. Jones, K.W., Sanders, D.C. (1987.): The influence of soaking pepper seed in water or potassium salt solutions on germination at three temperatures. Journal of Seed Technology, 97-102.

11. Khah, E.M., Passam, H.C. (1992.): Sodium hypochlorite concentration, temperature, and seed age influence germination of sweet pepper. HortScience, 27(7): 821-823.

12. Korkmaz, A., Korkmaz, Y. (2009.): Promotion by 5-aminolevulenic acid of pepper seed germination and seedling emergence under low-temperature stress. Scientia Horticulturae, 119(2): 98-102.

13. Liestiani, E., Fikri, E.N. (2012.): The Effect of Organic Fertilizer and Pesticides to Anthracnose Disease (Colletotricum Capsici) on Chili. Agroscientiae, 19(3): 165-169.

14. Lisjak, M., Tomić, O., Špoljarević, M., Teklić, T., Stanisavljević, A., Balas, J. (2015.): Garden cress germinability and seedling vigour after treatment with plant extracts. Poljoprivreda, 21(2): 41-46.

15. Mancini, V., Romanazzi, G. (2014.): Seed treatments to control seedborne fungal pathogens of vegetable crops. Pest management science, 70(6): 860-868. 
Svjetlana Matotan i sur.: Utjecaj tretmana sjemena na zdravstveno stanje sjemena i početni rast paprike

16. Mao, W., Lewis, J. A., Hebbar, P. K., \& Lumsden, R. D. (1997.): Seed treatment with a fungal or a bacterial antagonist for reducing corn damping-off caused by species of Pythium and Fusarium. Plant Disease, 81(5), 450-454.

17. Mateos, R.M., Bonilla-Valverde, D., del Rio, L.A., Palma, J. M., Corpas, F.J. (2009.): NADP-dehydrogenases from pepper fruits: effec tof maturation. Physiologia Plantarum, 135(2):130-139.

18. Mathur, S.B., Kongsdal, O. (2003.): Common laboratory seed health testing methods for detecting fungi 1 st Edition, International Seed Testing Association (ISTA), Bassersdorf.

19. Matotan, Z. (2004.): Suvremena proizvodnja povrća. Nakladni zavod Globus, Zagreb.

20. Nega, E., Ulrich, R., Werner, S., Jahn, M. (2003.): Hot water treatment of vegetable seed - an alternative seed treatment method to control seed-borne pathogens in organic farming. Journal of Plant Diseases and Protection, 220-234.

21. Nei, D, Enomoto K, Nakamura, N. (2015.): A gaseous acetic acid treatment to disinfect fenugreek seeds and black pepper inoculated with pathogenic and spoilage bacteria. Food microbiology, 49: 226-230.

22. O’Sullivan, J., Bouw, W.J. (1984.): Pepper seed treatment for low-temperature germination. Canadian Journal of Plant Science, 64: 387-393.

23. O’Sullivan, L., Jiwan, M.A., Daly, T., O’Brien, M.N., Aherne, S.A. (2010.): Bioaccessibility, up take, and transport of carotenoids from peppers (Capsicum spp.) using the coupled in vitro digestion and human intestinal Caco-2 cell model. Journal of agricultural and food chemistry, 58: 5374-5379.

24. Ozbay, N., Susluoglu, Z. (2016.): Assessment of growth regulator prohexadione calcium as priming agent for germination enhancement of pepper at low temperature. The Journal of Animal \& Plant Sciences, 26(6): 1652-1658

25. Palfi, M., (2007.): Skarifikacija sjemena lucerne (Medicago sativa L.) kiselinom. Sjemenarstvo, 24(1): 5-16.

26. Palfi, M.; Matotan, Z., Matotan, S. (2017a.): Utjecaj tretiranja sjemena stimulatorom klijanja Ekobooster 1 na početni rast $i$ razvoj paprike. Sjemenarstvo, 30 (1/2): 45-53.

27. Palfi, M., Ćosić, J., Vrandečić, K. (2017b.): Mogućnost primjene eteričnih ulja u suzbijanju bolesti sjemena. Zbornik sažetaka / Matotan, Z. (gl.ur.), Zagreb: Hrvatsko agronomsko društvo, 2017. str. 90-91.

28. Parađiković, N., Vinković, T., Radman, D. (2008.): Utjecaj biostimulatora na klijavost sjemena cvjetnih vrsta. Sjemenarstvo, 25(1): 25-33. 
Svjetlana Matotan i sur.: Utjecaj tretmana sjemena na zdravstveno stanje sjemena i početni rast paprike

29. Pravilnik o metodama uzorkovanja i ispitivanja kvalitete sjemena (NN 99/08).

30. Sadeghi, H., Delaviz, M., Pirasteh-Anosheh, H., Ranjbar, G. (2016.): Comparing the Effect of Seed Pre-Treatment Methods on Improving Alkali Stress Tolerance of Sainfoin and its Recovery. Iranian Journal of Seed Research, 3(1): 99-107.

31. Samarah, N.H., Wang, H., Welbaum, G.E. (2016.): Pepper (Capsicum annuum) seed germination and vigour following nanochitin, chitosan or hydropriming treatments. Seed Science and Technology, 44(3): 609-623.

32. Silva, L.R., Azevedo, J., Pereira, M.J., Valentão, P., Andrade, P.B. (2013.): Chemical assessment and antioxidant capacity of pepper (Capsicum annuum L.) seeds. Food and Chemical Toxicology, 53: 240-248

33. Sun, T., Xu, Z., Wu, C.T., Janes ,M., Prinyawiwatkul, W., No, H.K. (2007.): Antioxidant activities of different colored sweet bell peppers (Capsicum annuum L.). Journal of Food Science, 72: S98-S102.

34. Sutariati, G.A.K., Widodo, Sudarsono, Ilas, S., (2014.): Biological seed treatment focontrolling anthracnose disease of hot pepper. Journal of Sustainable Tropical Agricultural Sciences (IJSTAS), 1(1): 29-43.

35. Worrall, D., Holroyd, G.H., Moore, J.P., Glowacz, M., Croft, P., Taylor, J. E., Paul N.D., Roberts, M.R. (2012.): Treating seeds with activators of plant defence generates long-lasting priming of resistance to pests and pathogens. New Phytologist, 193(3): 770-778.

36. Yildirim, E., Dursun, A., Güvenc, I., Kumlay, A.M. (2000.): The effects of different salt, biostimulant and temperature levels on seed germination of some vegetable species. Proc II Balkan Symposium on Vegetables and Potatoes, Tirana (Albania), October 9-12. 579 (pp. 249-253).

Adresa autora - Author's address:

Mr. sc. Svjetlana Matotan

Dr. sc. Zdravko Matotan

Dr. sc. Marina Palfi

e-mail: marina.palfi@podravka.hr

Podravka d.d. Koprivnica

Ante Starčevića 32

48000 Koprivnica
Primljeno - Received

20.09.2018. 